\title{
A new Anthracoidea (Ustilaginales) Record for Turkey
}

\section{Türkiye için Yeni bir Anthracoidea (Ustilaginales) Kaydı}

\section{Research Article}

\section{Şanlı Kabaktepe ${ }^{1 *}$, llgaz Akata ${ }^{2}$, Şükrü Karakuş ${ }^{3}$}

'Inonu University, Battalgazi Vocational School, Battalgazi, Malatya, Turkey.

${ }^{2}$ Ankara University, Faculty of Science, Deparment of Biology, Ankara, Turkey.

${ }^{3}$ Inonu University, Faculty of Science and Art, Department of Biology, Malatya, Turkey.

\section{A B S TR AC T}

The smut species, Anthracoidea irregularis (Liro) Boidol \& Poelt (Anthracoideaceae) on Carex halleriana Asso

(Cyperaceae) was reported for the first time from Turkey. The morphological and microscopical features of this fungi are described with figures.

\section{Key Words}

Niğde, Aladağlar, New records, Ustilaginales.

\section{öz}

ir rastık mantarı türü olan Anthracoidea irregularis (Liro) Boidol \& Poelt (Anthracoideaceae), Carex halleriana Asso (Cyperaceae) bitkisi üzerinde Türkiye'den ilk kez kaydedilmiştir. Bu mantarın şekilleri ile morfolojik ve mikroskobik özellikleri, toplanan örneklere bağlı olarak tanımlanmıştır.

\section{Anahtar Kelimeler}

Niğde, Aladağlar, Yeni kayıt, Ustilaginales.

Article History: Received: Apr 8, 2018; Revised: May 3, 2018; Accepted: Jul 6, 2018; Available Online: Oct 4, 2018.

DOI: 10.15671/HJBC.2018.246

Correspondence to: Ş. Kabaktepe, Inonu University, Battalgazi Vocational School, Battalgazi, Malatya, Turkey. 


\section{INTRODUCTION}

$S$ muts are group of plant parasitic fungi belonging to the order Uredinales within the division Basidiomycota. The group includes more than 1200 species which could infect about 4000 different plant species, particularly cereals and grasses [1].

Anthracoidea (Anthracoideaceae) is a large genus of smut fungi and there are 106 species currently exist in the genus. The genus members infect infecting host plants in the Cyperaceae (mostly Carex sp.) and it is characterized by form globoid sori in the ovaries and spores produced on the outer surface of the reduced achenes [2,3].

According to literature [4-13], five confirmed Anthracoidea species on Carex sp ( $A$. angulata (Syd.) Boidol \& Poelt on Carex hirta L., A. caricis (Pers.) Bref. on Carex stenophylla Wahlenb., A. pratensis (Syd.) Boidol \& Poelt on Carex divisa Huds., A. pseudirregularis U. Braun on Carex sp., A. subinclusa (Körn.) Bref. on Carex stenophylla Wahlenb.) have hitherto been reported from Turkey but there is not any record of Anthracoidea irregularis (Liro) Boidol \& Poelt.
The current study aims to make contribution to the smut mycobiota of Turkey.

\section{MATERIALS and METHODS}

Materials were collected in 2013 from Kayseri and Mersin provinces in Turkey. The host specimens were prepared according to established herbarium techniques. Host plants identified use the Flora of Turkey and the East Aegean Islands [14]. Spores were scraped from dried host specimens. Microphotographs were taken under a light microscope (Noveks B series 1000). Analysis LS Starterwas software was used to measure. Identification was performed with the aid of literature $[1,3]$. The identified samples are deposited in the Inönü University Herbarium (INU).

\section{RESULTS AND DISCUSSION}

Basidiomycota

Ustilaginomycetes

Ustilaginales

Anthracoideaceae

Anthracoidea Bref.

Anthracoidea irregularis (Liro) Boidol \& Poelt (Figure 1).

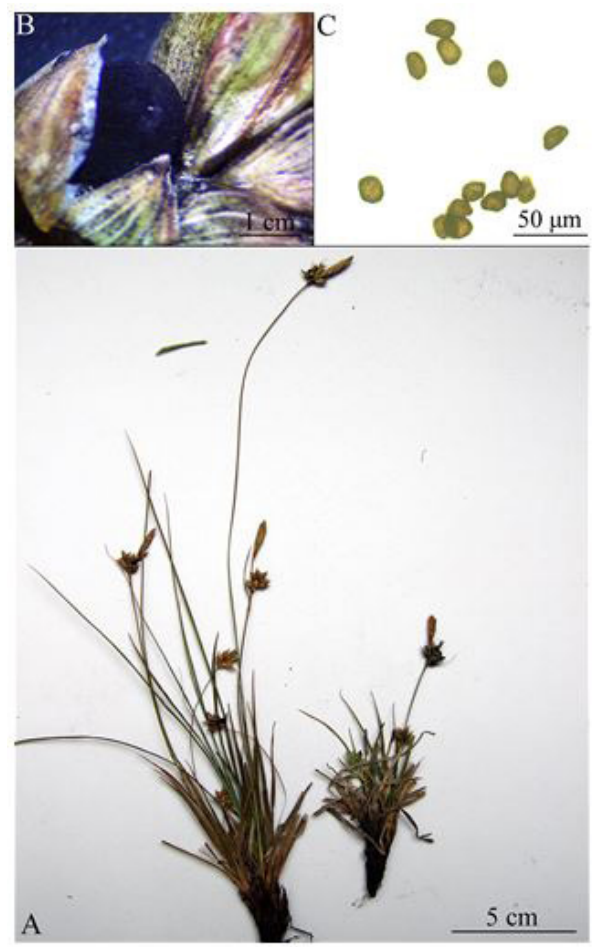

Figure 1. Anthracoidea irregularis A. dried herbarium specimen, B. SM view of Anthracocystis penniseti on sori, C. LM view of Teleutospores. 
Sori in ovaries, scattered in the inflorescence, forming globose to ovoid, hard, black bodies, 1-2 $\mathrm{mm}$ in diam., partly hidden by the glumes, surface powdery. Spores medium to large sized, distingly elongate, $13-22 \times 18-29(-34) \mu \mathrm{m}$, angular-irregular, sometimes rounded, medium dark reddish brown, wall uneven, $1-2,5(-3) \mu \mathrm{m}$ thick, thickest at the angles and protuberances, often with lightrefractive spot in the thickest area, sometimes 1-3 low internal swelling, surface finely to coarsely verruculose, spore profile finely wavy to serrulate.

Specimens examined - On Carex halleriana Asso (Cyperaceae): TURKEY-Niğde, Çamardı, Emli valley, 1800-1900 m, 25.06.2015, S. Kabaktepe \& I. Akata 8125 (INU 1210).

Distribution: On species of Carex (Cyperaceae) cosmopolitan, widespread in China, Mongolia, Japan, Europe [14].

\section{DISCUSSION}

Anthracoidea irregularis is easly distinguished from other Anthracoidea species by its germination type (Anthracoidea type), forming hard bodies on inflorescence, angular-irregular spores, surface of spores and warts thick, round or slightly elongated.

With the present study, Anthracoidea irregularis is reported for the first time from Turkey and it will be the $61^{\text {th }}$ species of smut fungi and the six Anthracoidea member growing on Turkish Carex species.

Acknowledgments - This study was supported by TUBITAK (Project no: 113Z093).

\section{References}

1. T.T.Denchev, C.M.Denchev, M.Michikawa,M.Kakishima, The genus Anthracoidea (Anthracoideaceae) in Japan and some adjacent regions. Mycobiota 2 (2013) 1-125.

2. M. Piatek, M. Lutz, M. Nobis, A. Nowak, Phylogeny and morphology of Anthracoidea pamiroalaica sp. nov. infecting the endemic sedge Carex koshewnikowii in the Pamir Alai Mts (Tajikistan). Mycol Progress (2015) 14:120.

3. K. Vánky, Smut Fungi of the World. APS press. St. Paul. Minnesota, 2012.

4. Z. Bahcecioglu, B.Yildiz, A study on the microfungi of Sivas Province. Turkish J. Bot. 29 (2005) 23-44.

5. Z. Bahcecioglu, S. Kabaktepe, B. Yildiz, Microfungi isolated from plants in Kahramanmaras Province, Turkey. Turkish J. Bot. 30 (2006) 419-434.

6. S. Kabaktepe, Z. Bahcecioglu, Microfungi identified from the flora of Ordu Province in Turkey. Turkish J. Bot. 30 (2006) 251-265.

7. S. Kabaktepe, Z. Bahcecioglu, New Anthracoidea, Tilletia, and Ustilago records for Turkey. Mycotaxon 122 (2012) 283-285.

8. Ş. Kabaktepe, I. Akata, H. Akgül, A New Anthracocystis (Ustilaginales) Record for Turkey. Hacettepe J. Biol. \& Chem. 44 (1) (2016) 21-24.

9. S. Kirbag, Two new records for the mycoflora of Turkey. Turkish J. Bot. 27 (2003) 153-154.

10. F. Petrak, Neue Beiträge zur Pilzflora der Türkei. Sydowia 7 (1953) 14-15.

11. N. Sahin, A.U. Tamer, Smut species determined in Turkey. J. Turk. Phytopath. 27 (1998) 151-156.

12. H.B. Sert, Additions to rust and smut fungi of Turkey. Phytoparasitica 37 (2009) 189-192.

13. H. B. Sert, H. Sumbul, M. Isiloglu, Phytopathogenic fungi new for Southern Anatolia, Turkey. Phytoparasitica 32 (2004) 402-408.

14. O. Nilsson, Carex L., In: P.H. Davis, editor. Flora of Turkey and the East Aegean Islands. Edinburgh University Press, Vol 9: 73. Edinburgh University Press, Edinburgh, 1985. 